\title{
Nilai Gizi Dan Daya Terima Es Krim Modisco Susu Kedelai Dengan Penambahan Buah Untuk Penanganan Anak Gizi Buruk
}

\author{
Findy Dwita Kumala*1, Sulasyi Setyaningsih ${ }^{2}$, Diah Ratnasari ${ }^{3}$ \\ 1,2,3 Program Studi Ilmu Gizi, Fakultas Ilmu Kesehatan, Universitas Muhadi Setiabudi Brebes, Indonesia \\ e-mail correspondance: *findhydwita2401@gmail.com
}

\begin{abstract}
ABSTRAK
Modisco (Modified Diet Skim Milks Sugar Cotton Seed) merupakan minuman tinggi energi 135 kalori untuk penanganan gizi buruk fase rehabilitasi sebagai pengganti formula WHO.Penelitian ini bertujuan untuk mengetahui pengaruh penambahan buah terhadap nilai gizi dan daya terima es krim. Penelitian ini menggunakan rancangan acak lengkap dengan 3 kali pengulangan. Perlakuan yang dilakukan dalam penelitian ini yaitu penambahan buah yang berbeda seperti strowberry, pisang dan alpukat. Pengujian yang dilakukan yaitu . energi, protein, lemak, kalium dan magnesium. Data kalium dan magnesium dianalisis menggunakan Anova. Pengujian daya terima dengan metode hedonik dan dianalisis menggunakan Repeated Measure.Hasil penelitian ini adalah Zat gizi per 100 gram es krim energi berkisar antara 135,28 sampai 140,98 kalori, protein 3,53 sampai 3,57 gram, lemak 107 sampai 110,9 gram. Kadar kalium rata-rata antara 1604,06 sampai 1765,3 ppm dan kadar magnesium rata-rata antara 116,1 sampai 253,8 ppm. Penambahan buah meningkatkan kesukaan dari segi warna, aroma, rasa dan tekstur, secara nyata penambahan buah yang paling disukai adalah pisang. Penelitian ini dapat disimpulkan bahwa Nilai gizi es krim modisco dengan penambahan buah (pisang, alpukat dan strawberi) memiliki nilai energi, protein, lemak yang melebihi standar modisco. Penambahan buah pisang dipilih karena memiliki nilai gizi yang tinggi dan daya terima paling disukai.
\end{abstract}

Kata kunci: kalium, magnesium, energi, protein, lemak

\begin{abstract}
Modisco (Modified Diet Skim Milks Sugar Cotton Seed) is a 135 calorie high energy drink for the treatment of malnutrition rehabilitation phase in lieu of the WHO formula. This research aims to find out the effect of fruit addition on the nutritional value and receiving power of ice cream. The study used a complete randomized design with 3 repetitions. The treatment carried out in this study is the addition of different fruits such as strowberries, bananas and avocados. The testing done is . energy, protein, fat, potassium and magnesium. Potassium and magnesium data are analyzed using Anova. Testing receiving power by hedonic method and analyzed using Repeated Measure.The results of this study are Nutrients per 100 grams of energy ice cream ranging from 135.28 to 140.98 calories, protein 3.53 to 3.57 grams, fat 107 to 110.9 grams. Potassium levels average between 1604.06 to 1765.3 ppm and magnesium levels average between 116.1 to $253.8 \mathrm{ppm}$. The addition of fruit increases the fondness in terms of color, aroma, taste and texture, in real terms the most preferred addition of fruit is bananas. This research can be concluded that the nutritional value of modisco ice cream with the addition of fruit (bananas, avocados and strawberries) has energy values, proteins, fats that exceed modisco standards. The addition of bananas was chosen because it has a high nutritional value and the most preferred receiving power.
\end{abstract}

Keywords: potassium, magnesium, energy, protein, fat

\section{PENDAHULUAN}

Masalah gizi pada hakikatnya adalah masalah kesehatan masyarakat, tetapi penanggulangannya tidak dapat dilakukan dengan pendekatan medis dan pelayanan kesehatan saja. Penyebab timbulnya masalah gizi adalah multifaktor, yaitu penyakit infeksi, kemiskinan dalam suatu populasi, pemberian makan yang tidak adekuat terkait dengan kebiasaan hidup, kondisi lingkungan dan kebutuhan dasar suatu populasi berupa pangan, papan dan kesehatan. 
Oleh karena itu pendekatan penanggulangannya harus melibatkan berbagai sektor yang terkait, seperti misalnya dari sektor pertanian meningkatkan produksi dan pengadaan pangan atau ketahanan pangan di tingkat rumah tangga[1].

Berdasarkan data Riskesdas 2018, prevalensi gizi kurang dan buruk di Indonesia pada tahun 2018 adalah 17,7\% dan masalah gizi yang baru muncul di masyarakat yaitu stunting atau tubuh pendek. Dari hasil beberapa penelitian menyatakan bahwa keadaan kurang gizi banyak dialami oleh bayi dan anak[2]. Bayi sampai balita, anak kemudian ibu hamil dan menyusui dalam ilmu gizi dikelompokkan sebagai golongan penduduk yang rawan terhadap kekurangan gizi termasuk Kurang Energi Protein (KEP)[3]. KEP disebabkan oleh masukkan energi dan protein yang kurang dalam waktu yang relatif lama. Keadaan ini akan lebih cepat terjadi apabila anak sakit, khususnya penyakit-penyakit infeksi. Pada keadaan kurang gizi anak akan lebih mudah terserang penyakit[4]. Dampak gizi buruk pada anak terutama balita yaitu pertumbuhan badan dan perkembangan mental anak sampai dewasa terhambat, mudah terkena infeksi dan bisa menyebabkan kematian bila tidak dirawat secara intensif[5].

Salah satu upaya yang bisa dilakukan adalah untuk mengatasi kekurangan gizi adalah dengan menciptakan makanan berkualitas serta dapat diterima oleh sasaran. Salah satunya adalah Modified Diet Skim Milk Sugar Cotton Seed (Modisco) yang merupakan minuman tinggi energi, mudah dicerna, murah serta mudah membuatnya[6]. Modisco yaitu minuman tinggi kalori yang formulanya terdiri dari susu skim, gula pasir dan minyak biji kapas. Untuk meningkatkan penerimaan di masyarakat maka formulanya diubah agar mudah diperoleh yaitu minyak biji kapas diganti dengan margarin. Modisco dapat diberikan pada anak yang membutuhkan tambahan kalori, kurang nafsu makan[7], serta penderita penyakit infeksi menahun, orang yang sembuh dari penyakit berat atau pasien dengan diit Tinggi Kalori Tinggi Protein (TKTP). Pada penelitian yang dilakukan di Rumah Sakit Umum dr. Soetomo Surabaya pemberian modisco dengan susu formula dan modisco susu formula elemental memiliki perbedaan yang bermakna dari sebelum dan sesudah pemberian[8]

Pada penelitian sebelumnya pemberian modisco memiliki pengaruh pemberian es krim modisco terhadap peningkatan berat badan balita gizi kurang. Modisco dapat digunakan sebagai pengganti formula $\mathrm{WHO}$, tetapi kelemahannya modisco tidak mengandung mineral mix atau larutan elektrolit yang berisi $\mathrm{KCl}$, tripotasium citrat, $\mathrm{Mg} \mathrm{Cl}_{2}{ }_{6} \mathrm{H}_{2} \mathrm{O}$, $\mathrm{Zn}$ asetat ${ }_{2} \mathrm{H}_{2} \mathrm{O}, \mathrm{Cu} \mathrm{SO}$, ${ }_{5} \mathrm{H}_{2} \mathrm{O}$ [8].Untuk mengatasi kelemahan modisco maka perlu adanya penambahan bahan makanan yang mengandung mineral yaitu dengan menambahkan buah-buahan. Modisco memiliki bentuk cair (enteral feeding) sehingga penerimaannya tidak begitu baik terutama bagi anak-anak. Untuk itu perlu dilakukan modifikasi dalam hal bentuk dan penambahan zat gizi lain, sehingga menjadi lebih berkualitas dan dapat diterima oleh balita terutama bagi mereka yang tergolong kekurangan gizi[9]. Salah satu modifikasinya yaitu es krim dengan bahan dasar modisco dengan penggunaan susu kedelai sebagai pengganti susu sapi. Pada penelitian sebelumnya dengan sampel pasien anak dengan gizi buruk terdapat perbedaan kecepatan anatara anak yang diberi modisco susu formula dengan susu formula elemental, yaitu kesemnuhan anak gizi buruk yang diberi modisco susu formula elemental lebih cepat dibanding yang diberi modisco susu formula[8]

Susu elementari adalah susu dengan kandungan lemak yang diperkecil dan kandungan zat gizi lain di perbanyak. Susu kedelai memiliki kadar protein 3,5 gr atau lebih tinggi dari susu sapi yang hanya memiliki kadar 3,2 gr per $100 \mathrm{ml}$ bahan[10]. Selain itu susu kedelai memiliki keunggulan memiliki harga yang murah dari pada susu hewani. Susu kedelai juga dapat dibuat dengan teknologi dan peralatan yang sederhana, serta tidak memerlukan ketrampilan khusus dalam proses pembuatannya. Susu kedelai juga cocok dikonsumsi oleh orang yang menderita "lactose intolerance" karena susu ini rendah laktosa. Kandungan vitaminnya pun cukup banyak antara lain vitamin $B_{2}$ Niasin, piridoksin, vitamin $E$ dan vitamin $K$ [11]

Selain memiliki kelebihan susu kedelai juga memiliki kekurangan yaitu adanya enzim lipoksigenase yang menyebabkan aroma langu. Sehingga sebagai upaya untuk mengurangi kelemahan ini yaitu dengan menambahkan bahan tambahann penghilang langu yaitu coklat bubuk sebanyak 5\% dari berat basah kacang kedelai yang merupakan bahan penghilang langu yang paling disukai[11]. Selain itu juga penambahan buah sebanyak 10\% dari jumlah total bahan 
pembuat es krim diharapkan mampu mengurangi aroma langu yang dihasilkan susu kedelai selain fungsi utamanya sebagai bahan makanan penambah mineral yang tidak ada pada modisco.

Buah yang digunakan adalah buah dengan kandungan kalium dan magnesium yang tinggi karena dua jenis mineral ini merupakan komponen utama penyusun larutan elektrolit. Mineral pada buah diharapkan memberikan asupan mineral yang dibutuhkan anak gizi buruk sebagai pemegang peranan penting dalam pemeliharaan fungsi tubuh. Kalium berfungsi menjaga keseimbangan elektrolit dalam sel tubuh, magnesium berfungsi sebagai kekebalan tubuh, mempertahankan otot normal dan fungsi saraf, menjaga irama jantung stabil dan membuat tulang kuat. Magnesium penting bagi pengobatan gizi buruk dalam mencegah seperti reaksi tetany dan di curtailing atau gejala gugup akibat kekurangan magnesium[12].

Dalam penelitian ini akan dibuat modifikasi modisco yang berupa es krim dengan pencampuran susu kedelai, modisco dan buah. Diharapkan dengan pencampuran beberapa bahan tersebut dapat menambah nilai gizi, daya terima dengan biaya pembuatan es krim yang terjangkau oleh masyarakat. Untuk itu perlu dilakukan pengujian mutu gizi yang meliputi energi, protein, lemak dan karbohidrat yang di hitung menggunakan Daftar Komposisi Bahan Makanan (DKBM), kadar kalium dan magnesium yang diuji di laboratorium, daya terima, serta analisis biaya bahan baku. Hal ini sesuai dengan persyaratan yang harus dipenuhi dalam modisco pada fase rehabilitasi, yaitu kandungan zat gizi per 100 gram, energi 135 kalori, protein 3,3 gram dan 7,5 gr lemak[12], serta adanya peningkatan mineral yaitu kalium dan magnesium dengan adanya penambahan buah-buahan, dapat diterima dengan baik oleh panelis serta terjangkaunya biaya bahan pembuatan modifikasi modisco tersebut.

\section{BAHAN DAN METODE}

Penelitian ini termasuk penelitian eksperimental yang dilakukan di Laboratorium Kimia Makanan dan Laboratorium Teknologi Pangan pada bulan Mei-Juni 2020 untuk penelitian awal dan bulan April untuk pembuatan produk. Variabel pengaruh dalam penelitian ini adalah berbagai penambahan buah sedangkan variabel terpengaruhnya adalah nilai gizi (energi, protein dan lemak) dan daya terima es krim modisco susu kedelai. Penelitian ini menggunakan rancangan acak lengkap untuk mengetahui adanya pengaruh penambahan buah terhadap nilai gizi dan daya terima es krim moodisco susu kedelai. Energi, protein, dan lemak dihitung menggunakan Daftar komposisi Bahan Makanan (DKBM). Sedangkan uji Kalium diuji di laboratorium, menggunakan metode Flame Atomic Absorption Spektophotometre (FAAS) pada panjang gelombang 766,5 nm dan uji magnesium menggunakan metode titrimetri.

Susu kedelai dibuat dengan cara merendam kacang kedelai selama 8 jam lalu rebus, buang kulit ari diblender dengan perbandingan air 1:8, saring lalu dipanaskan selama 15 menit dan ditambahkan coklat bubuk 5\% dari berat kedelai basah. Es krim modisco susu kedelai dibuat dengan cara susu kedelai dan buah diblender lalu campur dengan bahan modisco (susu full cream, gula pasir dan margarin) dikocok hingga homogen. Lalu ditambah whipped cream kocok selama 20 menit kemudian masukkan ke dalam freezer selama 30 menit pada suhu $-10^{\circ} \mathrm{C}$. Setelah 30 menit kocok lagi selama 15 menit kemudian diletakkan pada cup es krim dan dibekukan.

Kadar kalium dan Magnesium diuji di laboratorium. Uji daya terima es krim pada panelis agak terlatih dilakukan dengan menggunakan uji hedonik[13]. Analisis nilai gizi dilakukan dengan cara membandingkan dengan standar nilai gizi modisco per 100gram.

Uji Anova dilakukan untuk mengetahui pengaruh penambahan buah terhadar kadar kalium dan magnesium. Sedangkan uji Anova Repeated Measure dilakukan untuk mengetahui pengaruh komposisi bahan penyusun terhadap kadar daya terima panelis agak terlatih terhadap es krim modisco susu kedelai tersebut. 


\section{HASIL DAN PEMBAHASAN}

\section{Nilai Gizi}

Nilai gizi modisco pada fase rehabilitasi yaitu 135 kalori, 3,3gr protein, 7,5 gr lemak sedangkan nilai gizi yang didapat dari 100 gram es krim modisco susu kedelai dapat dilihat pada tabel 1 .

Tabel 1. Sumbangan nilai Gizi Es Krim Modisco Susu Kedelai Per 100 gram berdasarkan Standar Nilai Gizi Modisco Tahap Rehabilitasi.

\begin{tabular}{lclllll}
\hline $\begin{array}{c}\text { Penambahan } \\
\text { buah }\end{array}$ & $\begin{array}{c}\text { Energi } \\
(\text { Kkal) }\end{array}$ & \% Energi & $\begin{array}{c}\text { Protein } \\
(\mathbf{g r})\end{array}$ & \% Protein & $\begin{array}{c}\text { Lemak } \\
(\mathbf{g r})\end{array}$ & \% lemak \\
\hline Pisang & 140,98 & 104,4 & 3,575 & 108,33 & 8,32 & 110,9 \\
\hline Alpukat & 139,58 & 103,3 & 3,545 & 107,42 & 14,02 & 186,9 \\
\hline Strawberi & 134,28 & 99 & 3,535 & 106,96 & 8,025 & 107 \\
\hline Control & 133,12 & 98,6 & 3,481 & 105,48 & 7,52 & 100,2 \\
\hline
\end{tabular}

Tabel 1 menunjukkan bahwa Besarnya kandungan energi dalam setiap 100 gram es krim modisco susu kedelai berkisar antara 133,12 kkal - 140,98 kkal atau 98,6\% - 104,4\% dari kebutuhan setiap porsi modisco pada fase rehabilitasi penanganan gizi buruk. Sehingga kalori dari produk es krim modisco susu kedelai memenuhi standar modisco fase rehabilitasi yaitu 135 kalori dalam 100 gram. Besarnya kandungan protein dalam setiap 100 gram es krim modisco susu kedelai berkisar antara 3,48gr - 3,57gr atau $105,48 \%-108,42 \%$ dari standar kebutuhan fase rehabilitasi penanganan gizi buruk yaitu sebesar 3,3 gram. Sedangkan prosentase lemak dan karbohidrat antara 100,2\%-186,9\% dan 106,7\%-286,7\%.

Sumbangan energi terbesar yaitu pisang karena pisang memiliki nilai karbohidrat yang paling tinggi yaitu $286,7 \%$ dari kebutuhan dan kemudian alpukat karena alpukat memiliki kandungan lemak yang paling tinggi yaitu $186,9 \%$ dari kebutuhan standar modisco. Sumbangan yang memenuhi standar energi modisco yaitu 135 kalori dan protein 3,3 gram protein maka produk es krim ini dapat dijadikan alternatif modifikasi modisco yang dapat diberikan pada pasien gizi buruk sehingga pasien gizi buruk tidak merasa bosan dengan pemberian modisco tanpa modifikasi. Produk es krim modisco ini juga dapat diberikan untuk pasien yang menbutuhkan diit Tinggi Kalori Tinggi Protein (TKTP). Sumbangan energi terbesar yaitu pisang karena pisang memiliki nilai karbohidrat yang paling tinggi yaitu 286,7\% dari kebutuhan dan kemudian alpukat karena alpukat memiliki kandungan lemak yang paling tinggi yaitu $186,9 \%$ dari kebutuhan standar modisco. Aplikasi pemberian es krim modifikasi dari modisco ini bisa diberikan 6-10 kali sesuai dengan kondisi pasien. Takaran untuk 10 kali pemberian es krim per porsi dengan berat 100gram atau setara dengan cup es krim dengan diameter $5 \mathrm{sm}$ dan tinggi 4,5 cm sebanyak 2 cup dengan jumlah kalori $135 \mathrm{kkal}$.

2. Kadar Kalium

a. Kadar Kalium Es Krim Modisco Susu Kedelai

Analisa kadar Kalium secara laboratorium menggunakan metode FAAS pada panjang gelombang 766,5 nm. Kadar kalium es krim modisco susu kedelai dengan penambahan buah dapat dilihat pada tabel 2 .

Tabel 2. Kadar Kalium Es Krim Modisco Susu Kedelai dengan Penambahan Buah

\begin{tabular}{lcccccc}
\hline $\begin{array}{c}\text { Penambahan } \\
\text { buah }\end{array}$ & \multicolumn{3}{c}{ Pengulangan $(\mathbf{p p m})$} & $\begin{array}{c}\text { Rata-rata } \\
(\mathbf{p p m})\end{array}$ & $\begin{array}{c}\text { Standar } \\
(\mathbf{p p m})\end{array}$ & $\begin{array}{c}\text { Persentase } \\
(\mathbf{\%})\end{array}$ \\
\cline { 2 - 4 } Pisang & $\mathbf{1}$ & $\mathbf{2}$ & $\mathbf{3}$ & 2,066 & 2419 & 0,085 \\
\hline Alpukat & 1,637 & 2,395 & 2,167 & 2,066 & 2419 & 0,073 \\
\hline Strawberi & 1,593 & 1,628 & 2,102 & 1,774 & 2419 & 0,087 \\
\hline Control & 1,717 & 2,445 & 2,214 & 2,125 & 2419 & 0,06 \\
\hline
\end{tabular}

Hasil uji kadar kalium dapat dilihat pada gambar 1 


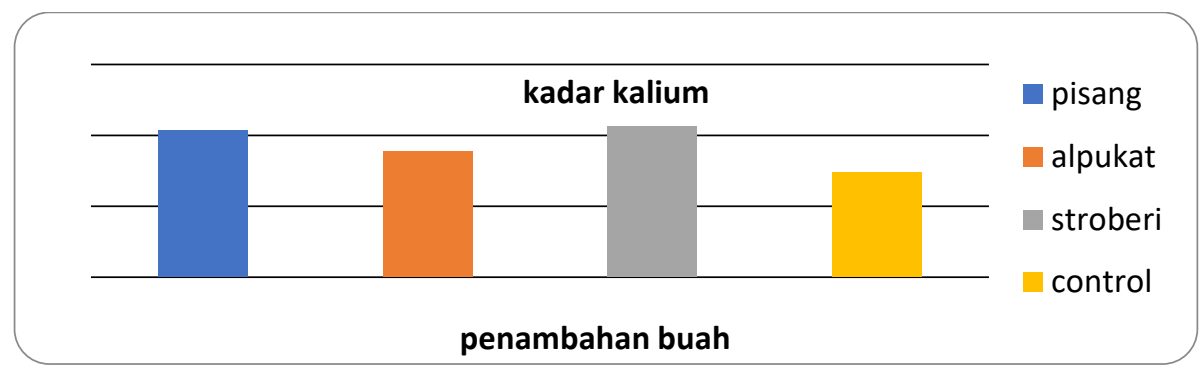

Gambar 1. Kadar Kalium es krim modisco susu kedelai

Dari hasil uji pengujian rata-rata kadar kalium dalam es krim modisco susu kedelai yang telah dijelaskan pada tabel 2 diatas menunjukan ada peningkatan kadar kalium dari penambahan berbagai jenis buah. Meskipun secara statistik tidak signifikan. Hasil uji kadar kalium dari yang paling tinggi yaitu strawberi, pisang dan alpukat. Hal ini sesuai dengan urutan kadar kalium pada Daftar Komposisi Bahan Makanan (DKBM) yang memiliki kadar kalium tinggi dan dapat diterima oleh balita dibanding buah yang lain. Walaupun memberikan sumbangan dalam jumlah yang sedikit namun kadar sampel yang ditambahkan lebih tinggi dibandingkan dengan yang tidak ada penambahan buahnya.

Persentase Kalium dibandingkan dengan standar kalium dalam 1 porsi es krim berkisar antara $0,06 \%-0,087 \%$, belum mencukupi standar yang seharusnya ada dalam modisco. Sehingga perlu adanya penelitian lebih lanjut untuk mendapatkan bahan tambahan yang dapat meningkatkan kadar kalium modifikasi modisco.

b. Pengaruh Penambahan Buah terhadap Kadar Kalium Es Krim Modisco Susu Kedelai

Untuk mengetahui pengaruh penambahan buah terhadap kadar kalium maka dilakukan uji Anova pada $\alpha=1 \%$. Berdasarkan uji Anova tersebut diketahui $p$-value 0,071 karena p-value 0,01 sehingga dapat disimpulkan tidak ada pengaruh penambahan buah terhadap kadar kalium dari es krim modisco susu kedelai tersebut.

3. Kadar Magnesium

a. Kadar Kalium Es Krim Modisco Susu Kedelai

Analisa kadar magnesium menggunakan metode titrimetri dan pada setiap pengukuran diulang sebanyak dua kali atau duplo. Kadar magnesium es krim modisco susu kedelai dengan penambahan buah dapat dilihat pada tabel 3

Tabel 3. Kadar Magnesium Es Krim Modisco Susu Kedelai

\begin{tabular}{|c|c|c|c|c|c|c|}
\hline \multirow{2}{*}{$\begin{array}{c}\text { Penambahan } \\
\text { buah }\end{array}$} & \multicolumn{3}{|c|}{ Pengulangan (ppm) } & \multirow{2}{*}{$\begin{array}{c}\text { Rata-rata } \\
(\mathbf{p p m})\end{array}$} & \multirow{2}{*}{$\begin{array}{c}\text { Standar } \\
(\text { ppm) }\end{array}$} & \multirow{2}{*}{$\begin{array}{c}\text { Persentase } \\
(\%)\end{array}$} \\
\hline & 1 & 2 & 3 & & & \\
\hline Pisang & 1,722 & 4,085 & 1,166 & 2,324 & 820 & $0,28 \%$ \\
\hline Alpukat & 1,783 & 1,166 & 4,664 & 2,538 & 820 & $0,30 \%$ \\
\hline Strawberi & 2,332 & 0,550 & 2,332 & 1,738 & 820 & $0,21 \%$ \\
\hline Control & 1,171 & 1,145 & 1,166 & 1,161 & 820 & $0,14 \%$ \\
\hline
\end{tabular}

Kadar magnesium es krim modisco susu kedelai dapat dilihat pada gambar 2

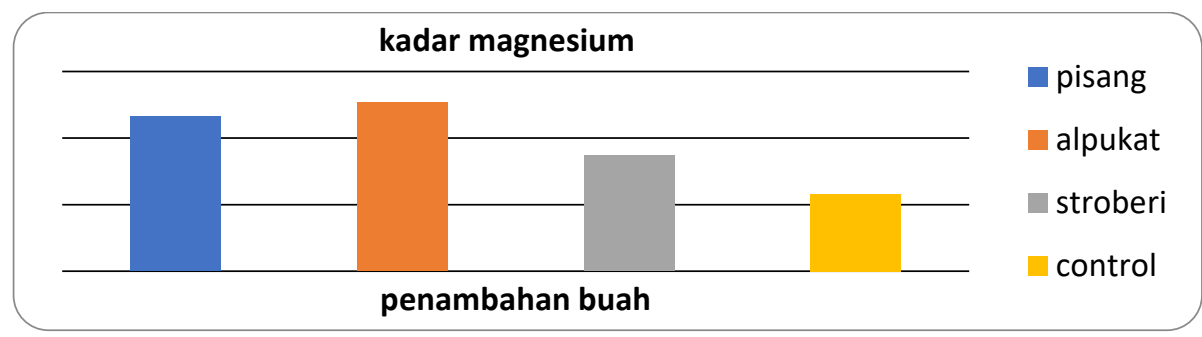

Gambar 2. Kadar Magnesium es krim modisco susu kedelai 
Dari hasil pengujian rata-rata magnesium dalam es krim modisco susu kedelai yang telah dijelaskan dalam tabel 2 diatas menunjukkan ada peningkatan kadar magnesium dari penambahan berbagai jenis buah dibandingkan dengan control atau tanpa diberi tambahan buah. Hasil uji laboratoium kadar magnesium yang memiliki nilai dari tertinggi yaitu alpukat, pisang dan strawberi. Urutan kadar magnesium dari yang tertinggi sama dengan kadar magnesium dari masing-masing buah dalam Daftar Komposisi Bahan Makanan (DKBM). Meskipun jumlah sumbangan magnesium dari es krim modisco susu kedelai tidak banyak namun kadar sampel yang diberi tambahan buah dengan yang tanpa penambahan buah lebih tinggi. Penambahan buah pada es krim modisco memberikan nilai persentase kadar magnesium antara 0,14\%-0,30\% dibandingkan dengan standar magnesium yang seharusnya ada pada modisco.

b. Pengaruh Penambahan Buah terhadap Kadar Magnesium Es Krim Modisco Susu Kedelai

Untuk mengetahui pengaruh penambahan buah terhadap kadar Magnesium maka dilakukan uji Anova pada $\alpha=1 \%$. Berdasarkan uji Anova tersebut diketahui p-value 0,597 karena p-value 0,01 sehingga dapat disimpulkan tidak ada pengaruh penambahan buah terhadap kadar magnesium dari es krim modisco susu kedelai tersebut.

4. Daya terima Es Krim Modisco Susu Kedelai dengan penambahan Buah

Tabel 5. Hasil Uji Daya Terima pada Panelis Agak Terlatih Es Krim Modisco Susu kedelai dengan Penambahan Buah

\begin{tabular}{|c|c|c|c|c|c|}
\hline \multirow{2}{*}{ Variabel } & \multicolumn{4}{|c|}{ Penambahan buah } & \multirow[b]{2}{*}{ p-value } \\
\hline & Pisang & Alpukat & Strawberi & Control & \\
\hline Warna & 3,9 & 2,75 & 3,4 & 2,15 & 0,000 \\
\hline Aroma & 3,6 & 2,9 & 2,95 & 2,35 & 0,000 \\
\hline Rasa & 3,5 & 3,05 & 2,3 & 2,85 & 0,000 \\
\hline Tekstur & 3,75 & 2,65 & 2,45 & 2,85 & 0,000 \\
\hline Rata-rata & 3,68 & 2,83 & 2,77 & 2,55 & \\
\hline Keterangan & Suka & Agak suka & Agak suka & Agak suka & \\
\hline
\end{tabular}

a. Warna

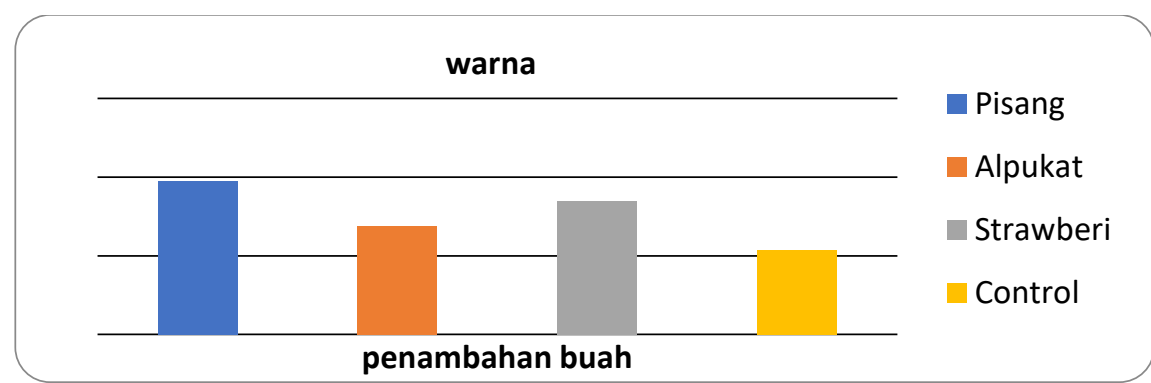

Gambar 3. Daya terima warna es krim modisco susu kedelai dengan penambahan buah

Berdasarkan hasil penilaian panelis terhadap warna es krim modisco susu kedelai diketahui bahwa penambahan buah yang paling disukai oleh panelis adalah es krim dengan penambahan buah pisang dengan jumlah skor 3,9 (suka). Sedangkan hasil penilaian yang lain termasuk dalam kategori agak suka dengan skor rata-rata untuk es krim dengan penambahan buah stawberi 3,4 dan penambahan buah alpukat 2,75 serta control atau tanpa diberi penambahan buah 2,15 (netral). Dari uji beda yang dilakukan dengan tingkat kepercayaan 99\% diketahui p-value 0,000 sehingga dapat disimpulkan ada pengaruh penambahan buah terhadap daya terima warna yang dihasilkan.

Berdasarkan uji Repeted Measure yang dilakukan dengan tingkat kepercayaan 99\% diketahui p-value 0,000, karena p-value < 0,01 sehingga dapat disimpulkan bahwa ada pengaruh penambahan buah terhadap warna es krim yang dihasilkan. 
Dari hasil rata-rata daya terima warna yang paling disukai adalah pisang kemudian strawberi, alpukat dan control. Kecenderungan warna yang disukai adalah warna coklat, karena buah-buahan yang digunakan mengandung polifenol oksidase dan substratnya, sehingga akan terjadi reaksi pencoklatan apabila jaringan terkena oksigen[14]. Penilaian kesukaan warna yang paling tinggi yaitu es krim dengan penambahan pisang dengan kategori suka dan penambahan buah yang lain dalam kategori agak suka.

b. Aroma

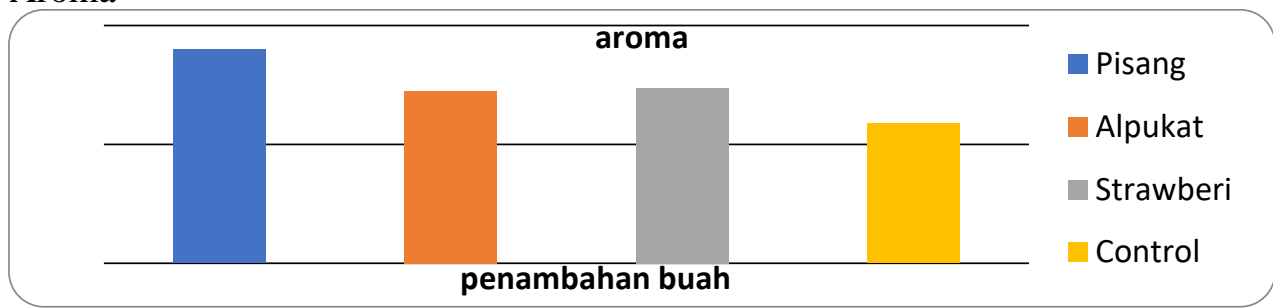

Gambar 3. Daya terima aroma es krim modisco susu kedelai dengan penambahan buah

Hasil penilaian panelis terhadap aroma es krim modisco susu kedelai diketahui bahwa penambahan buah yang paling disukai oleh panelis adalah es krim dengan penambahan buah pisang dengan jumlah skor 3,6 (suka). Sedangkan hasil penilaian es krim dengan penambahan buah yang lain termasuk dalam kategori agak suka dengan skor rata-rata untuk es krim dengan penambahan buah stawberi 2,95 dan penambahan buah alpukat 2,9 serta control atau tanpa diberi penambahan buah 2,35 (netral). Dari uji beda yang dilakukan dengan tingkat kepercayaan 99\% diketahui p-value 0,000 sehingga dapat disimpulkan ada pengaruh penambahan buah terhadap daya terima warna yang dihasilkan.

Berdasarkan uji yang dilakukan dengan tingkat kepercayaan 99\% diketahui pvalue 0,000 sehingga dapat disimpulkan bahwa ada pengaruh penambahan buah dengan aroma yang dihasilkan. Penilaian kesukaan terhadap aroma es krim dengan kategori suka pada penambahan pisang dan kategori agak suka pada penambahan strawberi dan alpukat. Sedangkan tanpa penambahan buah atau es krim control memiliki nilai terendah hal ini dikarenakan aroma langu yang biasanya terdapat pada kedelai dan hasil olahannya[15]. Enzim lipoksigenase yang secara alamiah memang banyak terdapat pada kacang-kacangan dan hasil olahannya dapat cegah dengan berbagai cara yaitu menggunakan air panas saat perandaman, penggilinan, perebusan pada pembuatan susu kedelai[12].Selain itu untuk mengurangi aroma langu dapat juga dilakukan dengan penambahan perasa seperti coklat bubuk, wijen, soda kue, vanili atau pandan. Namun penghilang aroma yang paling disukai adalah coklat bubuk[12].

c. Rasa

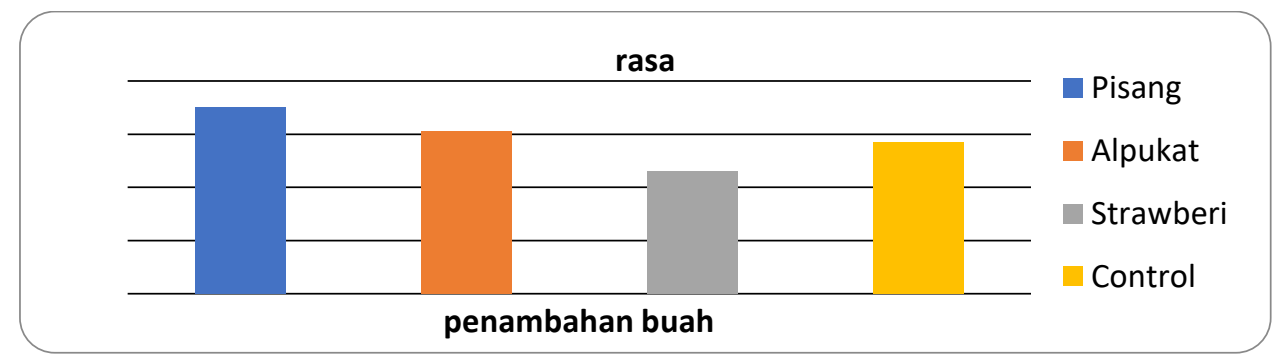

Gambar 4. Daya terima rasa es krim modisco susu kedelai dengan penambahan buah

Penilaian terhadap rasa es krim modisco susu kedelai diketahui bahwa penambahan buah yang paling disukai oleh panelis adalah es krim dengan penambahan 
buah pisang dengan jumlah skor 3,5 (suka). Sedangkan hasil penilaian es krim dengan penambahan buah yang lain termasuk dalam kategori agak suka dengan skor rata-rata untuk es krim dengan penambahan buah alpukat. Dan penambahan buah strawberi 2,3 (netral) serta control atau tanpa diberi penambahan buah 2,85 (agak suka) Dari uji beda yang dilakukan dengan tingkat kepercayaan $99 \%$ diketahui p-value 0,000 sehingga dapat disimpulkan ada pengaruh penambahan buah terhadap daya terima warna yang dihasilkan.

Hasil uji dengan tingkat kepercayaan 99\% diketahui p-value 0,000, karena pvalue $<0,01$ sehingga dapat disimpulkan bahwa ada pengaruh penambahan buah dengan rasa es krim yang dihasilkan. Rasa langu yang terdapat pada kedelai dan hasil olahnya[8], yang menyebabkan rasa yang khas pada produk selain menggunakan coklat bubuk sebagai perasa alami untuk mengurangi aroma langu, penambahan buah juga diharapkan mampu mengurangi rasa langu dai produk yang dihasilkan sehingga tingkat penerimaannya semakin baik.

d. Tekstur

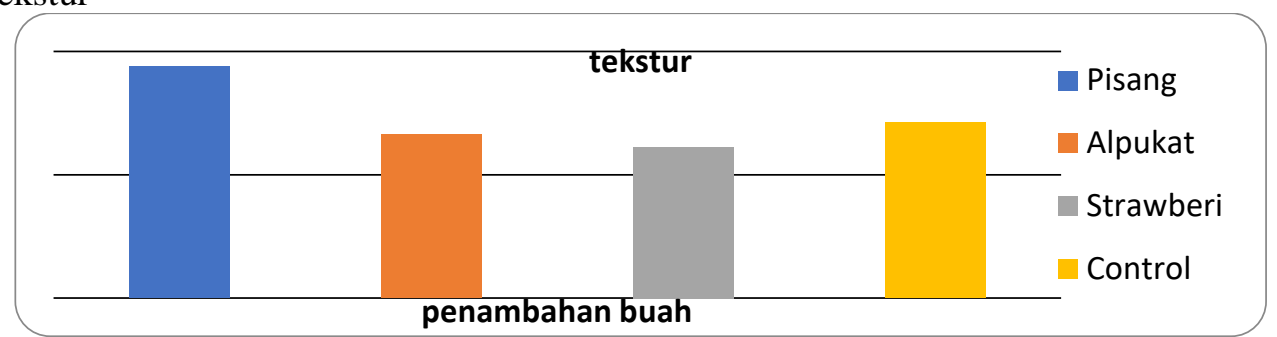

Gambar 5. Daya terima rasa es krim modisco susu kedelai dengan penambahan buah

Berdasarkan hasil penilaian panelis terhadap tekstur es krim modisco susu kedelai diketahui bahwa penambahan buah yang paling disukai oleh panelis adalah es krim dengan penambahan buah pisang dengan jumlah skor 3,75 (suka). Sedangkan hasil penilaian yang lain termasuk dalam kategori agak suka dengan skor rata-rata untuk es krim dengan penambahan buah alpukat 2,65. Dan penambahan buah strawberi 2,45 (netral) serta control atau tanpa diberi penambahan buah 2,85 (agak suka). Dari uji beda yang dilakukan dengan tingkat kepercayaan $99 \%$ diketahui p-value 0,000 sehingga dapat disimpulkan ada pengaruh penambahan buah terhadap daya terima warna yang dihasilkan.

Berdasarkan uji dengan tingkat kepercayaan 99\% diketahui p-value 0,000 karena p-value $<0,01$ maka dapat disimpulkan ada pengaruh penambahan buah dengan tekstur yang dihasilkan. Penambahan buah pada es krim modisco susu kedelai memberikan pengaruh terhadap penerimaan tekstur yang dihasilkan. Dengan kadar air pisang 72,8 gr dan alpukat $84,3 \mathrm{gr}^{8}$ lebih rendah dibandingkan dengan strawberi sehingga pada tekstur es krim dengan penambahan buah strawberi memiliki tingkat kesukaan yang paling rendah dibandingkan penambahan buah yang lain yang memiliki tekstur cenderung keras.

\section{Hasil Penelitian}

Penambahan buah pisang, alpukat dan strawberi pada es krim modisco susu kedelai memberikan peningkatan kadar kalium, magnesium dan daya terima meskipun secara uji statistik tidak signifikan atau tidak ada pengaruh penambahan buah terhadap kadar kalium dan magnesium, namun daya terima yang dihasilkan semakin baik. 
Tabel 7. Rekapitulasi Hasil penelitian Nilai Gizi dan Daya Terima Es Krim Modisco Susu Kedelai dengan Penambahan Buah

\begin{tabular}{|c|c|c|c|c|c|c|c|c|c|}
\hline \multirow[b]{2}{*}{ Penambahan } & \multicolumn{5}{|c|}{ Nilai gizi } & \multicolumn{4}{|c|}{ Daya terima } \\
\hline & $\begin{array}{c}\% \\
\text { Energi }\end{array}$ & $\begin{array}{c}\% \\
\text { Protein }\end{array}$ & $\begin{array}{c}\% \\
\text { lemak }\end{array}$ & $\begin{array}{c}\text { Kadar } \\
\text { K }\end{array}$ & $\begin{array}{c}\text { Kadar } \\
\text { Mg }\end{array}$ & Warna & Aroma & Rasa & Tekstur \\
\hline Pisang & 104,4 & 108,33 & 110,9 & 2,066 & 2,324 & 3,9 & 2,75 & 3,4 & 2,15 \\
\hline Alpukat & 103,3 & 107,42 & 186,9 & 1,774 & 2,538 & 3,6 & 2,9 & 2,95 & 2,35 \\
\hline Strawberi & 99 & 106,96 & 107 & 2,125 & 1,738 & 3,5 & 3,05 & 2,3 & 2,85 \\
\hline \multirow[t]{3}{*}{ Control } & 98,6 & 105,48 & 100,2 & 1,473 & 1,161 & 3,75 & 2,65 & 2,45 & 2,85 \\
\hline & & & & & & 3,68 & 2,83 & 2,77 & 2,55 \\
\hline & & & & & & Suka & $\begin{array}{l}\text { Agak } \\
\text { suka }\end{array}$ & $\begin{array}{l}\text { Agak } \\
\text { suka }\end{array}$ & $\begin{array}{l}\text { Agak } \\
\text { suka }\end{array}$ \\
\hline
\end{tabular}

Penambahan buah seperti pisang, alpukat dan strawberi memberikan peningkatan terhadap kadar kalium maupun kadar magnesium meskipun hasil yang diperoleh memiliki nilai yang tidak terpaut jauh, namun hasil uji secara statistik tidak signifikan.

Besarnya persentase energi dan protein per 100 gram es krim berdasarkan standar modisco fase rehabilitasi sangat memenuhi yaitu berkisar antara 133,12 kkal - 140,98 kkal atau 98,6\% $104,4 \%$ dan 3,48gr - 3,57gr atau 105,48\% - 108,42\% dari standar kebutuhan. Maka produk es krim ini dapat dijadikan alternatif modifikasi modisco yang dapat diberikan pada pasien gizi buruk sehingga pasien gizi buruk tidak merasa bosan dengan pemberian modisco tanpa modifikasi. Produk es krim modisco ini juga dapat diberikan untuk pasien yang menbutuhkan diit Tinggi Kalori Tinggi Protein (TKTP). Tingkat penerimaan daya terima yang baik meskipun susu kedelai memiliki kelemahan berupa aroma langu namun dengan pengolahan yang sesuai dan dengan penambahan bahan penghilang aroma langu seperti coklat bubuk dan berbagai jenis buah memberikan pengaruh terhadap daya terima es krim modisco susu kedelai.

\section{KESIMPULAN}

Berdasarkan penelitian yang dilakukan diperoleh kesimpulan sebagai berikut, tidak ada pengaruh penambahan buah terhadap kadar kalium es krim modisco susu kedelai. Namun ada peningkatan kadar kalium dibandingkan dengan yang tanpa diberi penambahan meskipun secara statistik tidak signifikan. Tidak ada pengaruh penambahan buah terhadap kadar magnesium es krim modisco susu kedelai. Namun ada peningkatan kadar magnesium dalam es krim dengan penambahan buah dibandingkan dengan tanpa penambahan buah atau control meskipun secara statistik tidak signigfikan. Ada pengaruh penambahan buah terhadap daya terima menurut penambahan buah dan ada pengaruh penambahan buah terhadap penialaian daya terima pada es krim dengan penambahan pisang dan es krim dengan penambahan strawberi. Berdasarkan tabulasi data daya terima penilaian yang paling baik adalah es krim modisco susu kedelai penambahan pisang dengan kategori suka. Besarnya sumbangan energi dan protein es krim modisco susu kedelai berdasarkan standar modisco pada fase rehabilitasi penanganan gizi buruk per 100 gram, yaitu antara $98,6 \%-104,4 \%$ dan $105,48 \%-108,33 \%$.

\section{DAFTAR PUSTAKA}

[1] Supriasa, "Penilaian Status Gizi Edisi Revisi," in Penerbit Buku Kedokteran: EGC, 2012.

[2] Dinas Kesehatan Jawa Tengah, "Provinsi Jawa Tengah Tahun 2015," Profil Kesehat. Provinsi Jawa Teng., 2015, doi: 10.1016/j.ajo.2008.04.036.

[3] Hardiansyah and I. D. Supariasah, Ilmu Gizi Teori dan Aplikasi. 2017.

[4] D. Solihin, M.R.D., Anwar.F., Sukandar, "Kaitan Antara Status Gizi,Perkembangan Kognitif, Dan Perkembangan Motorik Pada Anak Usia Prasekolah," Penelit. Gizi dan Makanan, 2013.

[5] K. Nadhiroh, Siti Rahayu; Ni'mah, "Faktor yang berhubungan dengan kejadian," Media 
Gizi Indones., 2010.

[6] A. Arolyumna, S. Prihatin, and D. N. Subandrian, "PENGARUH PEMBERIAN ES KRIM MODISCO TERHADAP KENAIKAN BERAT BADAN PADA BALITA GIZI KURANG," J. Ris. Gizi, 2016.

[7] Y. Susanti, M. Devi, and S. Katmawanti, "EFEKTIVITAS PELATIHAN PEMBUATAN PMT MODISCO TERHADAP PENGETAHUAN IBU DI KELURAHAN TANJUNGREJO KECAMATAN SUKUN KOTA MALANG," Prev. Indones. J. Public Heal., 2018, doi: 10.17977/um044v3i1p14-22.

[8] R. Irawan, "Perbedaan Kecepatan Kesembuhan Anak Gizi Buruk yang Diberi Modisco Susu Formula dan Modisco Susu Formula Elemental Di RSU dr. Soetomo Surabaya," Sari Pediatr., 2016, doi: 10.14238/sp8.3.2006.226-30.

[9] S. B. Kuntardjo, Suharto, Sarana, and Paryono, "Program Penerapan Teknologi Tepat Guna Untuk Produksi Makanan Olahan Hasil Pertanian Di Magelang," in Prosiding Seminar Nasional Unimus, 2018.

[10] Kasnodihardjo, "NILAI-NILAI BUDAYA YANG MENDASARI PEMERATAAN MAKANAN YANG DAPAT MENUNJANG GIZI KELUARGA," Bul. Penelit. Kesehat., 2014.

[11] B. P. dan P. P. Kementerian Pertanian, Adaptasi Perubahan Iklim Sektor Pertanian. 2011.

[12] K. Kesehatan et al., "Petunjuk Teknis TataLaksana Anak Gizi Buruk Buku II," Koko, 2011.

[13] S. Syafitri, W. Priawantiputri, and M. Dewi, "Produk biskuit sumber zat besi berbasis bayam dan tepung sorgum sebagai makanan tambahan ibu hamil," J. Ris. Kesehat. Poltekkes Depkes Bandung, 2019, doi: https://doi.org/10.34011/juriskesbdg.v11i2.676.

[14] R. Ambarwati, "PENGEMBANGAN MAKANAN TAMBAHAN BERBASIS F100 DENGAN SUBSTITUSI TEPUNG LABU KUNING DAN TEPUNG PISANG," J. Nutr. Coll., 2020, doi: 10.14710/jnc.v9i2.27033.

[15] R. Susanti and F. Fibriana, "Teknologi Enzim,” Universitas Neger Semarang. 2017. 